\title{
Historical Agricultural Landscape as a Subject of Landscape Ecological Research
}

\author{
Jana Špulerová, František Petrovič
}

\begin{abstract}
This article is focused on historical agricultural landscapes in Slovakia, which have been preserved and have irreplaceable ecological, cultural and historical value. Historical structures of agricultural landscapes (HSAL) are a type of cultural landscape that contains, within a geographic area, both natural and man-made features that typify connected activities, and a cultural expression reflecting past events or patterns of physical development. They are now becoming rare, making them even more valuable, however, on a European scale. The article presents an overview of research activities focused on the historical agricultural landscape and point out different types of historical agricultural landscapes such as viticulture landscapes, mountain grassland-arable landscapes, agricultural landscapes with dispersed settlements etc. The research emphasized land-use changes, driving forces, and threats and trends relating to the historical agricultural landscape in Slovakia.
\end{abstract} Slovakia

Key words: historical agricultural landscape, cultural landscape, landscape ecology,

\section{Povijesni poljoprivredni pejzaž kao predmet istraživanja ekologije pejzaža}

Rad se bavi očuvanim povijesnim poljoprivrednim pejzažima u Slovačkoj, čija je ekološka, kulturna i povijesna vrijednost neprocjenjiva. Povijesne strukture poljoprivrednih pejzaža (engl. HSAL) tip su kulturnog pejzaža koji unutar geografskog područja posjeduje prirodne i ljudskom rukom nastale komponente pejzaža koje predstavljaju njihovu tipičnu poveznicu te kulturni izričaj koji odražava prošle događaje i obrasce fizičkog razvoja. Takve strukture danas su sve rjeđe te je stoga njihovo očuvanje još važnije. Ovaj je rad pregled istraživačkih aktivnosti usmjerenih na povijesne poljoprivredne pejzaže te izdvaja različite tipove poljoprivrednih pejzaža, poput vinorodnih, planinskih travnato-obradivih, $\mathrm{s}$ disperznom naseljenošću itd. Istraživanje naglašava promjene iskorištavanja zemljišta, faktore promjene, prijetnje i trendove povezane s poljoprivrednim povijesnim pejzažima u Slovačkoj. Slovačka

Ključne riječi: povijesni poljoprivredni pejzaž, kulturni pejzaž, ekologija pejzaža, 


\section{TRADITIONAL HISTORICAL LANDSCAPE AS PART OF CULTURAL HERITAGE}

The present cultural landscape is the result of an interaction over several thousand years between Man and Nature. The significance of this interaction is that history is linked together with ecological, landscape and aesthetic values, and they increase landscape diversity and diversity of life forms in tandem with the maintenance of natural and cultural heritage in Slovakia (Hrnčiarová, 2009). If we would wish to understand the present landscape, we would have to know the history and evolution of the landscape. Historical and present land use tells us many things about the socio-economic state of the local community, and society as a whole. Valuing the land and sustainable development refer to ways and trends of the development of society and its response to social-political influences or changes. Considering the time scale of land use, we can distinguish (Jančura, 1998):

- Present land use represented by the present state of land cover, in a time frame of not more than 5 years.

- Historical land use represented by the historical time series of land use.

If the historical landscape structure is still preserved, the original and preserved landscapes, where human activities through history consciously transformed the environment, can be described as traditional historical landscapes (Huba, 1988). Each traditional landscape expresses a unique sense or spirit of place (genius loci) that helps to define its identity (Antrop, 2000). In Europe, with its long and complex history and great cultural diversity, a rich variety of traditional landscapes emerged, which form an integral part of our cultural heritage. Traditional historical landscape is not significantly affected by present innovative technologies, intensification of agriculture, industry, transport development or the mining industry, which is considered as the most significant intervention in the landscape that started in the second half of the $20^{\text {th }}$ century. Traditional landscapes are changing with increasing speed and an important cultural heritage is being lost (Van Eetvelde and Antrop, 2004). Traditional historical landscapes represent a specific, time-limited pattern of landscapes that have often been preserved as small-scale isolated fragments. They represent part of our cultural heritage and they are valued due to their biological or anthropogenic significance (Huba, 1988). The factors forming landscapes natural as well as human activities - are a basis for understanding landscape as an integrated unit (Supuka, 1998). The position and uniqueness of signs creating the landscape value, as well as identification of symptoms as visual disorders, enable identification of landscape values and landscape character (Jančura and Daniš, 2008).

Landscape creates a frame for the definition of the cultural heritage of certain regions. Traditional historical landscapes are displayed in the Landscape Atlas of the Slovak republic (Podolák et al., 2002), which describes several groups of the traditional use of cultural landscapes that were preserved after the period of the intensification of agriculture, e.g. traditional meadow-pasture landscapes, landscapes with traditional scattered settlements, historical landscapes with small farm buildings or with water mills, historical landscapes of mixed types - folk architecture and cultural mosaic, etc.

Hrnčiarová (2004) classifies historical landscapes into 5 categories: viticulture, agrarian landscape with a mosaic of strip-narrow fields, historical mining areas, fishing 
point areas and spa areas. Viticulture is represented by small vineyards that include pinned vineyards, terraces, rocky mounds, unconsolidated walls, or wine cellars. The agrarian historical landscape is characterized by a mosaic of strip-narrow fields, often with a preserved traditional settlement. Historical mining areas with the presence of roads and heaps have a special position in the field of historical landscape structures and they shelter much information about the contemporary ways of life that can be read from them (Hudecová, 2006).

A condition for the protection of cultural heritage monuments and historic sites, in accordance with scientific knowledge and on the basis of international conventions in the field of European and world cultural heritage to which the Slovak Republic has acceded, governs the Act of NC SR No. 49/2002 on the protection of monuments and historic sites. The object of protection is cultural heritage, which means a set of movable and immovable property, including imported work and thoughts, which found a place and application in Slovakia. The work of visual, household and folk art, monuments of folk architectonics, relics of manufacture, science and technology, historical gardens, parks and cultural landscapes is also considered as movable cultural heritage, formed by Man. Attention is being paid mostly to movable cultural heritage. Traditional historical landscape and its elements such as water mills, tessellated fields, alleys, scattered settlements and others can be considered as cultural landscapes, but they are not valued by society as they are seen to be common. From the landscape ecological point of view, these elements seem to be a well-defined group of landscape elements that should be not overlooked. This landscapeecological view will increase our scientific knowledge about these historical monuments as well as about their value, and give support to the reason for their protection and the preservation of characteristic views and vistas.

\section{HISTORICAL STRUCTURES OF AGRICULTURAL LANDSCAPES}

Agricultural landscape covers almost half of the area of the Slovak republic, and it is significant from the production as well as the ecological point of view. Within the agricultural landscape of Slovakia, the unique islands of species-rich plant and animal communities originated by continuous succession over centuries can still be found. These biotopes originated due to human intervention and they depend on continuous management. They are a result of a long-term mutual relationship between Man and the landscape. However, due to complicated development trends in society, they have been marginalized, and are currently no longer the subject of interest from a production perspective. Generally, they can be defined as biotopes of historical structures of agricultural landscape (HSAL). HSAL are a type of cultural landscape that contains, within a geographic area, both natural and man-made features that typify connected activities and a cultural expression bearing on past events or patterns of physical development (Dobrovodská and Štefunková, 1996, Dobrovodská, 2000). These areas are now becoming rare, making them even more valuable on a European scale. They represent a mosaic of small-scale arable fields and permanent agricultural cultivations. As the main sources of local biodiversity, they are linked to balks and margins of cross field tracks, original meadows and pastures, grass-grown former arable fields abandoned after collectivization, small wetlands or other low production or unfavourable areas (Ružičková et al., 1999). They have irreplaceable ecological, cultural and 
historical value. HSAL provide humans with many services, most of which currently have no market value. HSAL with preserved original forms of anthropogenic relief ameliorate regional climate, and preserve the soil from devastating erosion. Grasslands contribute to maintaining a large genetic library and the composition of the atmosphere (Costanza et al., 1997). These structures have attached weight to the landscape by their unique impression and they have become a subject of landscape-ecological research (e.g. Miklós et al., 1996, etc.). Historical landscape structures were assessed in relation to natural conditions and traditional culture (Miklós et al., 1996; Štefunková and Cebecauer, 2006), as well as in correlation to agricultural development and land use changes (Jančura, 2004; Štefunková and Dobrovodská, 2009).

As the topic and influence of scientific fields is broad, the view of different scientists is also varied. Historical landscape and questions of perception and values of the environment, as well as the understanding of environmental quality, is an important component of the sustainability and quality of life (Huba, 2004). Historical landscape structures are a significant feature, which have to be considered with tourism development (Krnáčová et al., 2005). They represent our natural and cultural heritage and they are often part of the cultural landscape of the Biosphere reserve (Olah, 2003; Olah et al., 2006). Unique landscape character, for example, creates terraced relief of agricultural landscape and structure forms in Pieniny National Park, together with Prielom Dunajca (cliff relief) and well-preserved folk architecture (Kul'anda and Slámová, 2008).

Since these areas are not a subject of special protection at present and since there are no specific policies intended to preserve or manage cultural value in agricultural landscapes, the landscape in general is an object of several national policy documents. Some documents are partially or more focused on historical agricultural landscapes, and their conservation, management and landscape planning, e.g. National law: The Act on Nature and Landscape Protection of Historic Sites, The Conceptual Framework of Agricultural Development for 2007 - 2013, The Conceptual Framework of Nature and Protection (2006), The Rural Development Program of the SR for 2007 - 2013, The National Environmental Action Plan (NEAP II 2004), The Proposal for the Implementation of the European Landscape Convention in the SR (2005), etc. The aim of the maintenance of historical agricultural landscape is not strict conservation, but preservation, protection and restoration of the cultural and natural value of the area, and the preservation of characteristic views and vistas in accordance with sustainable development. Integration of sustainable development is dependent on tools and funding schemes that should contribute to biodiversity conservation, optimal land use improving the management of agricultural landscapes and, ultimately, to rural and environmental sustainable development.

Even the HSAL are the subject of landscape ecological research. There is a lack of scientific information about the HSAL, their significance and distribution around Slovakia that could be a basis for legislative procedures, their protection and management and for their being valued by society. Most knowledge is based upon case studies and local data. Therefore, the Institute of Landscape Ecology wanted to fill these gaps and launched a project in 2009 focused on the inventory of HSAL around Slovakia, and the evaluation of their biodiversity in correlation to the environmental, socio-economical and anthropogenic condition of the area. Inventory of HSAL is being done by analysis of aerial photos using 
the $1 \mathrm{~km}^{2}$ network created in Google Earth and GIS. Approximately $10 \%$ of the sites, which were identified on aerial photo as areas with potential occurrence of HSAL, were selected by statistical sampling and they were validated and mapped in the field (Špulerová et al., 2009; Dobrovodská et al., 2010). A tool for field mapping, methodology and a Handbook for field mapping were developed, emerging from the definition of HSAL and the mapping key for HSAL (Fig. 1).

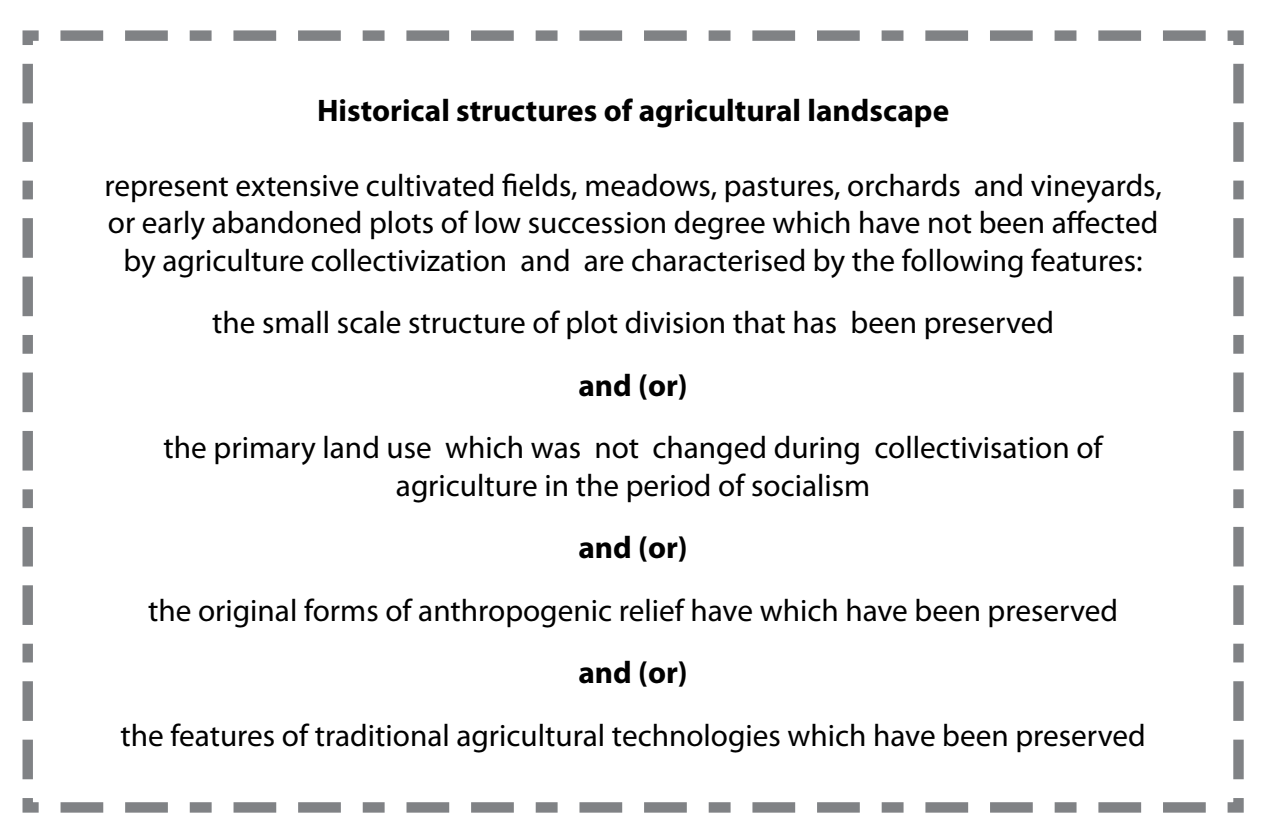

Fig. 1 Mapping key of historical structures in an agricultural landscape

Sl. 1. Definicija povijesnih struktura u poljoprivrednom pejzažu

\section{TRENDS IN AND THREATS TO HISTORICAL AGRICULTURAL LANDSCAPE}

Agricultural landscapes with preserved historical landscape structures, traditional agricultural technologies or ecological-friendly farming, with the presence of natural or semi-natural habitats represent a significant part of our cultural heritage. The main threats to these are land development and intensive agriculture.

As a response to global trends in agriculture at an international or European level, which cause degradation of the agricultural landscape and the loss of biodiversity, new solutions are being considered for optimal multifunctional land use of the agricultural landscape. Not only food production, but the needs of society, too, are growing for recreational, aesthetical and environmental services, as well as for ecological stability. In the context of historical agricultural landscape and the need for its maintenance, the following are considered the source of identity and trails of historical development, traditional technologies, manners, land ownership, plot division, as well as outcomes of 
legislative and economic-political conditions of certain periods. We are looking for new land use of traditional structures flowing from actual trends in agrarian policy, as well as the needs and requirements of local municipalities and regions. First of all, it is necessary to put together all the information about these structures and the measure of their present use and threats. Genesis of historical monuments or structures, their origination in landscapes, their development and finally their extinction is conditioned in principle from two sides. It depends on social-economical as well as natural relations. The configuration of landscape structures is changing and there is a risk of the slow loss of its originality and uniqueness. HSAL are threatened by abandonment and succession, expansion of the coverage of nonforest woody vegetation and decreases in the number of fragments of historical landscape structures. It is a consequence of the culmination of population. In the middle of the $20^{\text {th }}$ century, the population ebb took place, followed by the change of land management and changes in the components of land cover structure (Jančura et al., 2008).

As an example we can show case studies of regions with dispersed settlement (Petrovič, 2007). Most of the dispersed settlements originated as a consequence of Walachian colonization. This colonization was conditioned by certain historic-societal-economical circumstances and it was reflected by its spatial expression. The beginning of the settlement and colonization of primeval forested landscapes was connected with the foundation of enclaves of arable fields and meadows, usually with dispersed rural settlement, called "kopanice" in Slovakian. This movement and settlement was significantly influenced by space and natural determinateness. First, the most accessible area and most fertile soils were populated. Later, when most of the fertile soils were cultivated, mountain and borderland regions were settled and colonized. As with the origin, the decline, too, of this specific landscape is related to social and economic conditions. The transition of agriculture to co-operative and mechanized socialist farming in the last century had caused most of these old traditional agricultural areas to become insignificant. Due to changes in agricultural farming and the decline or elimination of cattle and sheep breeding, some grassland areas became abandoned.

The main threats to biodiversity are abandonment and reforestation as a consequence of changes in employment structure or a decrease in residents. Growing trends enable secondary succession and the spread of weed species and grasses, tree self-seeding etc. Certain landscapes are devastated and that causes a loss of biodiversity. There is a loss of traditional landscape and its genius loci and maintenance is dependent on human activity. We have seriously to consider and look for new ways to preserve them for the next generation. Since they are situated in less accessible, remote and marginal mountain or sub-mountain areas with extreme Nature conditions, as well as unfavourable economic and demographic indicators characteristic for such regions, financial contribution by the state is indispensable. One of the tools to maintain the biodiversity of agricultural landscapes is an agro-environmental scheme along with subsidies for less favourable areas and for biodiversity protection of habitats of European significance. The challenge for the preservation of historical agricultural landscapes could be supported by an agroenvironmental scheme, if they were to be considered as significant landscape elements, and a new scheme and conditions for subsidies for these specific landscape elements would be developed. 
The future of traditional landscapes and historical agricultural landscapes will depend on the following question. Can the public be sensitized to the maintenance of this important part of our cultural heritage, and can we find ways to combine the conservation and management of these areas and elements with modern economic systems and lifestyles?

\section{CONCLUSION}

The target of the Slovak Republic in compliance with the European Landscape Convention is to identify its own landscapes throughout its territory; and to assess them, taking into account the particular values assigned to them by those interested. Historical agricultural landscapes are one of the particular types of landscape in Slovakia. Their originality consists in their delimited area.

Historical structures of agricultural landscape are recognized in the landscape types of their high cultural-historical value, and this has become a motivation for us to study these structures and to develop a strategy for protection and maintenance of historic agricultural landscape. The studied historical structures represent remarkable areas in the light of the interaction between Man and Nature. Even though changes in the land use of agricultural landscape were very dramatic over the last 50 years, the impact on biodiversity and landscape in the studied areas of HSAL was not so strong as compared with other regions of Slovakia. Following the present trends of abandonment and intensification, HSAL are exposed to destruction. Therefore, special attention should be paid to them, as they represent the dominant landscape features of studied areas and we have to look for new ways in which to preserve them for the next generation.

The researched scientific knowledge can support the development of relevant legislation measures for the conservation of the biodiversity and cultural heritage of this precious agricultural landscape. The HSAL database can also be utilized as a valuable source for territorial planning at regional and national levels. It is also of utmost importance for the development of related legislative measures, for research activities and for international cooperation in the protection and management of agricultural landscapes.

\section{ACKNOWLEDGEMENTS}

This research was prepared within the grant project of the Ministry of Education of the Slovak Republic and the Slovak Academy of Sciences No. 2/0114/10 "Identification of Purposive Landscape Features as the Basis of Landscape Ecological Research". 


\section{REFERENCES}

Act of NC SR No. 49/2002 on the protection of monuments and historic sites

Antrop, M., 2000: Background concepts for integrated landscape analysis. Agric. Ecosyst. Environ. 77, 17-28.

Costanza, R., R. d‘Arge, R. de Groot, S. Farber, M. Grasso, B. Hannon, K. Limburg, S. Naeem, R.V. O’Neill, J.Paruelo, R.G. Raskin, P. Sutton M. Van den Belt, 1997: The value of the world? The ecosystem services and natural capital. Nature 357, 253-260.

Dobrovodská, M., 2000: Historická krajinná štruktúra - Liptovská Teplička. Životné prostredie, 34, 5, 267-269.

Dobrovodská, M., Štefunková, D., 1996: Historické pol'nohospodárske formy angropogénneho reliéfu v oračinovolúčno-pasienkarskej a vinohradníckej krajine. Acta Enviro. Univ. Comen., Bratislava, 7, 85-91.

Dobrovodská, M., Špulerová, J., Štefunková, D., Halabuk, A., 2010: Research and maintenance of biodiversity in historical structures in the agricultural landscape of Slovakia. In: Barančoková, M., Krajčí, J., Kollár, J., Belčáková, I. (eds.), Landscape ecology - methods, applications and interdisciplinary approach. Institute of Landscape Ecology, Slovak Academy of Sciences, Bratislava, 131-140.

Hrnčiarová, T., 2004: Prírodné a kultúrne aspekty krajiny a jej potenciál. Životné prostredie, 38, 2, 61-65.

Hrnčiarová, T., 2009: Indikátory hodnotenia zmien krajiny ako prvky historickej krajinnej štruktúry Slovenska. In. Pucherová, Z., Vanková, V. (eds.): Problémy ochrany a využivania krajiny - Teórie, metódy a aplikácie : zbornik vedeckých prác. Združenie BIOSFÉRA, Nitra, 133-142.

Huba, M.,1988: Historické krajinné štruktúry. Ochranca prírody, odborná príloha spravodajca MV SZOPK Bratislava, 1-62.

Huba, M., 2004: Historické štruktúry krajiny v kontexte súčasnej reality. Životné prostredie, 38, 2, 2004, s. 86- 89.

Hudecová, B. 2006: Príspevok k poznaniu historických krajinných štruktúr v stredoslovenskej banskej oblasti. Contribution to historical landscape structure in middle Slovakia - Mining region. In Venkovská krajina. Sbornik prispevku. ZO ČSOP Veronica, 64-67.

Jančura, P., 1998: Súčasné a historické krajinné štruktúry v tvorbe krajiny. Životné prostredie, 32, 5, 236-240.

Jančura, P. eds., 2004: Historické krajinné štruktúry vo vzt'ahu k vývoju pol’nohospodárskeho využivania zeme. Partner, Banská Bystrica, 115 pp.

Jančura, P., Kul'anda, M., Hrčková, L., Daniš, D., 2008: Factors of state changes of landscape cover structure on example of Ostrôžky upland settlement In: Benčat', T., Jančura, P., Daniš, D. Vybrané problémy krajiny podhorských a horských oblastí. Partner, Poniky. 111-120.

Jančura, P., Daniš, D., 2008: Characteristic Appearance of the Landscape. Životné prostredie, 42, 2, 59-63.

Krnáčová, Z. et al., 2005: Integrovaný rozvoj turizmu v mikroregióne Svätý Jur. ÚKE SAV, Bratislava, 171 pp.

Kul'anda, M, Slámová, M.: Typy usporiadania historických foriem agroštruktúr v Pieninskom Národnom parku. In: Benčat', T., Jančura, P., Daniš, D. Vybrané problémy krajiny podhorských a horských oblastí. Partner, Poniky. 2008, p. 61-68.

Miklós, L. a kol.: Prírodné podmienky a kultúra využitia krajiny. Kultúrno-historické a krajinnoekologické podmienky rozvoja Banskej Štiavnice, Svätého Jura a Liptovskej Tepličky. Banská Štiavnica : Nadácia UNESCO-Chair for ecological awareness, 1996, $102 \mathrm{~s}$.

Olah, B., 2003: Vývoj využitia krajiny Podpol'ania - Starostlivost'o kultúrnu krajinu prechodnej zóny BR Pol’ana, Vedecké štúdie 1/2003/B. TU Zvolen, Zvolen, 111 p.

Olah, B., Boltižiar, M., Petrovič, F., Gallay, I., 2006: Vývoj využitia krajiny slovenských biosférických rezervácií UNESCO, Vedecké štúdie 2/2006/B. TU a SNK MaB, Zvolen, 140 pp.

Petrovič, F., 2007: Originalita rozptýleného osídlenia na Slovensku. Enviromagazín, 3: 24-25.

Podolák at al., 2002: Traditional land use and traditional culture. In: Hrnčiarová et al. (ed) Atlas of the landscape of the Slovak republic. Bratislava. 
Ružičková, H., Dobrovodská, M., Valachovič, M., 1999: Landscape-ecological evaluation of vegetation in relation to the forms of anthropogenic relief in the cadastre of Liptovská Teplička village, the Nízke Tatry Mts. Ekológia (Bratislava), 18, 4: 381-400.

Supuka, J, 1998: Vegetačné formácie ako nástroj tvorby krajiny. Životné prostredie, 32, 5, 229-232.

Špulerová, J., Dobrovodská, M., Štefunková, D., Halabuk, A., 2009): Metodika mapovania historických štruktúr pol'nohospodárskej krajiny. In Kontrišová et al. (ed) Monitorovanie a hodnotenie stavu životného prostredia VIII. Zbornik referátov. TU Zvolen.

Štefunková, D., Cebecauer, T., 2006: Visibility analysis as a part of landscape visual quality assessment. Ekológia (Bratislava). 25, Suppl. 1, 229-239.

Štefunková, D., Dobrovodská, M., 2009: Preserved European cultural heritage in agrarian landscape of Slovakia. Tájökológiai Lapok, 7, 2, 283-290.

Van Eetvelde, V., Antrop, M., 2004: Analyzing structural and functional changes of traditional landscapes - two examples from Southern France, Landscape and Urban Planning, 67, 1-4: 79-95.

Received (Primljeno): 2010 - 12 - 31

Accepted (Prihvaćeno): 2011 - 09 - 30

Eng. Jana Špulerová, PhD.

Institute of Landscape Ecology

Slovak Academy of Sciences

Bratislava

jana.spulerova@savba.sk

Assoc. Prof., RNDr. František Petrovič, PhD.

Department of Ecology and Environmentalist

Faculty of Natural Sciences

Constantine The Philosopher University Nitra fpetrovic@ukf.sk 
